\title{
Сюжетно-типологические особенности сказания «Богдо Чаңгар хан» в традиции тувинцев и эпоса «Джангар» в национальных версиях калмыков России и ойратов Синьцзяна"
}

\author{
Цаган Б. Селеева
}

Калмыцкий научный центр Российской академии наук, Российская Федерация

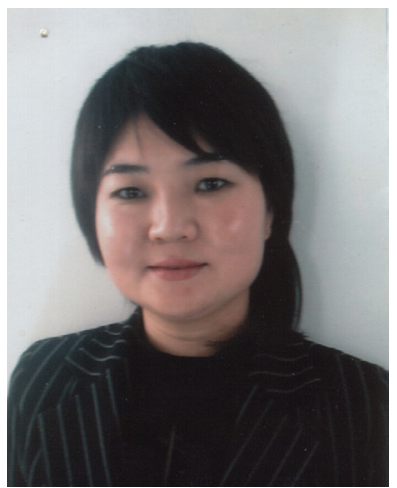

В статье рассматривается сказание «Богдо Чаңгар хан», бытовавщее в тувинской эпической традиции, с точки зрения установления сюжетно-типологических параллелей с эпосом «Джангар» калмыцкой и синьцзян-ойратской версий.

Сказание о Джангаре, созданное и сформированное в тувинской эпической традиции, в поэтической структуре сохранило черты своей древней самобытной культуры, черты патриархального уклада и родо-племенной идеологии, жанрового синкретизма героического эпоса и волшебно-герочческой сказки, сказочно-мифологического пласта, восходящего к архачческим сказаниям тюрко-монгольских народов Сибири. Вместе с тем обнаруживаются типологические схождения с калмыцким и синьцзян-ойратским «Джангаром» на уровне тем и сюжетов, мотивов и образов, циклической организации.

Выявлено, что распространение и бытование сказания о Джангаре в традиции тувинцев было связано с развитым культом эпического героя Джангара и обусловлено древнейшими историко-культурными и этническими связями с ойратами, особенно сильным влияние было в период существования Джунгарского ханства.

Ключевые слова: Богдо Чангар хан; Джангар; эпос; сказание; типология эпоса, эпическое сказание; сюжет; мотив; тувинцы; калмыки; ойраты; Синьцзян; тюрко-монгольская эпика

* Исследование проведено в рамках государственной субсидии - проект «Устное и письменное наследие монгольских народов России, Монголии и Китая: трансграничные традиции и взаимодействия» (номер госрегистрации АААA-А19-119011490036-1).

Для цитирования:

Селеева Ц. Б. Сюжетно-типологические особенности сказания «Богдо Чаңгар хан» в традиции тувинцев и эпоса «Джангар» в национальных версиях калмыков России и ойратов Синьцзяна[Электронный ресурс] // Новые исследования Тувы. 2019, № 4. URL: https://nit.tuva.asia/nit/article/view/889 (дата обращения: дд.мм.гг.). DOI: 10.25178/nit.2019.4.11

Селеева Цаган Бадмаевна - кандидат филологических наук, научный сотрудник отдела монгольской филологии, Калмыцкого научного центра Российской академии наук. Адрес: 358000, Россия, г. Элиста, ул. им. И. К. Илишкина, д. 8. Тел.: +7 (4722) 3-55-06. Эл. адрес: tsagana007@mail.ru ORCID ID: 0000-0002-3285-3038

Seleeva Tsagan Badmaevna, Candidate of Philology, Research Associate, Department of Mongolian Philology, Kalmyk Scientific Center of the Russian Academy of Sciences. Postal address: 8 Ilishkin St., 358000, Elista, Russian Federation. Tel.: +7 (4722) 3-55-06. E-mail: tsagana007@mail.ru 


\title{
Story-typological features of the legend "Bogdo Changar Khan" in the tradition of Tuvans and the epic "Dzhangar" in the national versions of the Kalmyks of Russia and the Oirats of Xinjiang"
}

\author{
Tsagan B. Seleeva \\ Kalmyk Scientific Center of the Russian Academy of Sciences, Russian Federation
}

\begin{abstract}
The article examines the legend of 'Bogdo Changar Khan' once integral to the Tuvan epic tradition, establishing its plottypological parallels to Kalmyk and Xinjiang-Oirat versions of the 'Jangar' epic.

The legend of Changar (Jangar) that was created and took shape within the Tuvan epic tradition has retained some structural poetic features of the ancient original culture, bearing traces of the patriarchal lifestyle and indigenous ideology, genre syncretism of the heroic epic and magic-heroic tale, mythological layers rooted in archaic narratives of Siberian Turko-Mongols. At the same time, it shows certain typological affinities with Kalmyk and Xinjiang-Oirat Jangar texts in terms of themes and plots, motifs and images, definite cyclical structures.

The paper reveals the dissemination and existence of the legend about Changar (Jangar) in the Tuvan tradition was closely related to the cult of the epic hero Changar (Jangar) and determined by most ancient historical, cultural and ethnic ties with the Oirats that reached their peak during the era of the Dzungar Khanate.
\end{abstract}

Keywords: Bogdo Changar Khan; Jangar; epic; legend; epic typology, epic narrative; plot; motif; Tuvans; Kalmyks; Oirats; Xinjiang; Turko-Mongolic epics

"The reported study was funded by government subsidy - project name 'Oral and Written Heritage of the Mongolic Peoples of Russia, Mongolia and China: Cross-Border Traditions and Interactions' (registration number AAAA-A19-119011490036-1).

\section{For citation:}

Seleeva T. B. Story-typological features of the legend "Bogdo Changar Khan" in the tradition of Tuvans and the epic "Dzhangar" in the national versions of the Kalmyks of Russia and the Oirats of Xinjiang. The New Research of Tuva. 2019, № 4. URL: https://nit.tuva.asia/nit/article/view/889 (access date ...). DOI: 10.25178/nit.2019.4.11

\section{Введение}

На протяжении ряда столетий тюркские и монгольские племена, объединенные кочевой культурой, находились в постоянном контакте в силу связанности и общности социально-исторических условий. Одним из высших достижений культуры кочевников стал героический эпос, сохранивший сходство древних реликтов и культов, истории и языка, ранних форм верований, мифологических и религиозных представлений, традиционного мировоззрения и социальных институтов.

К монументальным и значимым творениям эпического творчества тюрко-монгольских народов Центральной Азии, наряду с «Гэсэром», относится и эпос «Джангар». Джангариада является основным эпическим памятником ойратоязычных этносов - калмыков России, ойратов Китая (Синьцзяна) и Монголии. В виде отдельных сказаний «Джангар» бытует у сарт-калмыков, халха-монголов, бурят, тувинцев и алтайцев.

Тувинский героический эпос, как и эпос тюрко-монгольских народов Сибири, по мнению исследователя С. М. Орус-оол (Орус-оол, 2011: 35), стадиально относится к самому раннему героикоархаическому типу. По сравнению с историко-героическим эпосом (русские былины, «Манас», «Джангар», «Алпамыш») в нем отражены идеалы общинно-родового строя. В эпической традиции тувинцев бытовали известные сказания «Богатырь Кунан-Хара», «Силач Сагаан-Тоолай», «При взрослении не имеющий возраста, при смерти не имеющий душу Эр-Дунсай», «Одинокий Эрсен-оол» и др. Близость историко-культурных связей с монгольскими народами находит подтверждение в бытовании у 
тувинцев монгольских сказаний «Гэсэр» и «Богатырь Хан-Хара», а самым известным сказанием является ойратский эпос «Чаңгар» («Джангар»).

Известно, что сказания о Джангаре бытовали также в среде тувинцев, живших на Алтае в соседстве с западномонгольскими ойратскими племенами. Интересные сведения об этом сообщает исследователь Э. Таубе: «24 августа 1967 г. в юрте друзей в Ольгий мы встретились случайно с 70-летней сказительницей Албачини Байа, у которой записали восемь небольших сказок, которые она услышала в детстве от своего отца Албачи. Когда мы заговорили о ее отце, она сказала: “Когда я была маленькой, мой отец вечерами рассказывал 61 историю о Джангаре при зажженной жертвенной свече (воскурение)”. Байа называет своего отца “хара багшы”, т. е. тот, кто получил основное образование в одном из ламаистских монастырей, а потом стал мирянином: далее она охарактеризовала своего отца как человека, знающего монгольский и тибетский языки и много читавшего. Вероятно, что он слышал “Джангар” в одном из ойратских монастырей. Монгольское влияние сказывается еще и в том, что Байа называла свои сказки “улигер”, а не общепринятым тувинским термином “толл”. На вопрос, может ли она рассказать чтонибудь из тех историй о “Джангаре”, она решительно ответила “нет”. Мы узнали, что в начале века среди тувинцев нынешнего цэнгэльского сомона “Джангар” бытовал не как пересказ определенных текстов для развлечения, а как рассказы, которые имеют магическо-ритуальную функцию, на что указывает воскурение можжевельника. Эти и объясняется решительное “нет” сказительницы на мой вопрос» (Таубе, 2004: 172-173).

Э. Таубе отмечает, что «Джангар» уже не бытует в репертуаре известных современных сказителей алтайских тувинцев, но отдельные его сюжеты неоднократно встречаются. «Это свидетельствует о том, что в Западной Монголии и Джунгарии, у живущих там монгольских и тюркоязычных племен, определенные сюжеты были известны и получили распространение еще в начале XVII века, т. е. до того, когда часть ойратов ушла оттуда к нижней Волге. К ним относятся такие сюжеты из цикла «Джангара», которые известны и алтайцам» (Таубе, 2004: 173).

Целью настоящей статьи является рассмотрение сказания о Джангаре, представленного в тувинской эпической традиции, с точки зрения установления сюжетно-типологических схождений с эпосом «Джангар» калмыцкой и синьцзян-ойратской версий, что даёт возможность пролить свет на актуальные вопросы происхождения и развития, особенности бытования эпоса в национальных традициях, выявления фольклорных и этнокультурных взаимосвязей.Исследование основано на тексте тувинского эпического сказания «Богдо Чаңгар хан», опубликованного в 1973 г. в переводе Д. С. Куулара в филологической серии выпуска «Ученых записок» Калмыцкого научно-исследовательского института языка и литературы (Богдо Чаңгар хан, 1973: 122-127). В качестве сравнительного материала привлекаются репрезентативные тексты эпоса «Джангар» калмыцкой версии Ээлян Овла: «О пленении прекраснейшим в мире Мингъяном могучего хана Кюрмена» (Джангар, 1990: 102-116), «О пленении могучего Бадмин Улана богатырями Хара Джилганом, Аля Шонхором и Хошун Уланом» (там же: 139-152), «О подчинении Алтан Чееджи мудрого [Джангару]» (там же: 16-20); тексты-соответсвия синьцзянойратской версии: «О том, как Прекраснейший в мире Мингъян взял живым в плен и привез Могучего Кюрмен-хана» (Джангар, 2005: 373-394), «О том, как Хошун Улан, Хара Джилган, Аля Шонхор втроем взяли вплен Бадмин Улана» (Джангар, 2006: 521-546), «О битве Алтана Чеджи со Славным Джангаром» (Джангар, 2005: 93-102). Отдельные аспекты данной проблематики исследовались в работах (Кичиков, 1973; Куулар, 2004; Мелетинский, 2004; Орус-оол, 2011; Таубе, 2004).

\section{Сюжетные особенности сказания «Богдо Чаңгар хан»}

В сентябре 1957 г. в глухом урочище отдаленного Тоджинского района Тувы известным исследователем Д. С. Кууларом был найден престарелый рапсод Балбыр Баян Узунович, из уст которого удалось записать несколько эпических сказаний, в том числе сказание «Богдо Чаңгар хаан». Сюжет сказания повествует о хане Чаңгаре и героических подвигах его сына Чаңгар Чиргилчинниг Шил-оола (Куулар, 2004: 143).

Как-то хан Чаңгар сообщил своим подданным о наступлении срока упреждающего похода против могущественного хана северной стороны Канмыл-Какпа. Он озадачился поисками богатыря, кому было бы под силу совершить столь трудный поход и одолеть противника. Чуть позже становится ясно, что никто кроме сына Чаңгара Чиргилчинниг Шил-оола (Алмазного мальчика) не решится совершить поход в далекую страну Канмыл-Какпа, находящуюся на расстоянии девяностолетней езды. Шил-оол, оседлав стройного рыжего коня, отправился в далекий путь на север. 
Преследуемый чертями и дьяволами, герой пробыл в пути долгих шесть лет. Приехав в страну хана Канмыл-Какпа, поднявшись на вершину девятигранной горы, увидел он целый город, столицу государства. Невдалеке от города заметил юрту ламы-отшельника Аржи. Превратив коня в захудалого жеребенка, себя в мальчишку в косульей шубе, отправился он к ламе. Пока лама спал, приняв угощение хозяйки, выпил он весь көгээр. Возмущения хозяйки по этому поводу было столь сильным, что проснулся хозяин-лама. Он признал в госте отпрыска хана Чаңгара и отругал жену. Шил-оол, остерегаясь, что они донесут о нем ханским стражникам, расправился с ними и отправился в ханскую столицу.

С большим трудом он пробрался сквозь ряды ханского войска к обители хана и узнал, что хан спит, а сторожат его два черных богатыря и пара огромных сторожевых псов. Используя смекалку и хитрость, Шил-оол отвлек охрану, обезглавил спящего хана и, перескочив поверх трех рядов ханских войск, скрылся в ночи. Стража, обнаружив мертвыми хана с хатун, схватили лук и стрелы, поднялись на священную синюю гору. Один из стражников обнаружил Шил-оола, ехавшего по гребню десятигранной Красной горы, и пустил в него стрелу. Сраженный вражеской стрелой, истекая кровью, богатырь лишился жизни прямо в седле. Верный конь привез хозяина к юрте Богдо Чаңгара. Хан обнаружил притороченную к седлу голову Канмыл-Какпа и мертвого сына. Созвав народ кочевья, хан стал искать человека, кто смог бы оживить его сына. Тем временем конь богатыря поднялся в верхний мир и спустился с девой Ногаан Дангыны (Изумрудной девой), чудесным образом исцелившей Шил-оола. Спустя время Шил-оол отразил нападение войск Канмыл-Какпа и уничтожил посланного небесным ханом серого кролика, волшебным образом умножавшего войска противника. Приняв прозрачный облик, Шил-оол отправился с войском и завоевывал страну Канмыл-Какпа. После этого Богдо Чаңгар провозгласил ханом сына вместо себя и тот ханствовал еще очень долго. (Изложение сюжета приведено по переводу Д. С. Куулара (Богдо Чаңгар хан, 1973: 122-127).

Сказание «Богдо Чаңгар хан» относится к Джангариаде, имевшей широкое хождение в Центральной Азии. Оно стоит особняком в списке тувинских эпических произведений, отличаясь стилем повествования, фабулой, атрибутикой героического, ономастикой и топонимией (Куулар, 2004: 143). Но вместе с тем, сказание определенно сформировано в рамках тувинской эпической традиции, «о чем свидетельствуют такие признаки, как язык (тоджинский диалект тувинского языка), типологическое родство с другими эпическими творениями тувинцев, собственные имена богатырей (за исключением имени Чаңгар) и др.» (Кичиков, 1973: 118).

В сюжетно-повествовательном плане сказание схоже с отдельными главами калмыцкого и синьцзянойратского «Джангара», в которых прослеживается тенденция к генеалогической циклизации поколений «отец-сын» («О поражении свирепого Шара Гюргю», «О том, как Хошун Улан, Хара Джилган, Аля Шонхор втроем взяли в плен Бадмин Улана»). Такого рода сюжетные повествования, по мнению С. М. Орус-оол (Орус-оол, 2011: 36), свойственны героическим сказаниям тюрко-монгольских народов Сибири. В них события изображаются в биографическом плане: жизнь героев второго поколения показана от их рождения до возвращения к себе на родину после завершения подвигов.

Сюжет рассматриваемого тувинского сказания повествует об обеспокоенности хана Чаңгара угрозой, исходящей от могущественного хана северной стороны Канмыл-Какпа. Намереваясь нанести противнику упреждающий удар, Чаңгар с подданными озадачен поиском богатыря, способного одолеть сильного врага. Выясняется, что только его сын Чиргилчинниг Шил-оол, исполнен решимости отправиться в дальний поход. Герой Чиргилчинниг Шил-оол, преодолев долгий и сложный путь полный опасностей и приключений, достигает земель могущественного хана Канмыл-Какпа. Юный герой расправляется с противником и отправляется в обратный путь, захватив с собой голову убитого им хана. Стража, обнаружившая мертвыми хана с хатун, пускается в погоню за героем и, настигнув, смертельно ранит его стрелой. Конь героя спасает и доставляет лишенного жизни хозяина домой, затем отправляется в верхний мир за небесной девой, которая чудесным образом исцеляет юного богатыря. Спустя время, герой Чиргилчинниг Шил-оол, приняв прозрачный облик, расправляется с войском хана Канмыл-Какпа. После победы над войском могущественного противника отец Богдо Чаңгар провозглашает сына ханом.

\section{Сюжетно-типологические особенности сказания «Богдо Чаңгар хан» и сюжетов калмыцкой и синьцзян-ойратской версий эпоса «Джангар»}

Значительным схождением с тувинским сказанием «Богдо Чаңгар хан» отмечен сюжет калмыцкой и синьцзян-ойратской версий «О пленении могучего Бадмин Улана богатырями Хара Джилганом, Аля 
Шонхором и Хошун Уланом», повествующий об опасности, исходящей от могущественного противника, поиске правителем исполина, способного исполнить поручение и противостоять могучему врагу, нахождении юного героя, отправившегося вместе с юными богатырями-соратниками в поход и пленившего врага. Сюжет выстраивается вокруг давнего конфликта правителя Джангара с неким Бадмин Уланом - Джангар в поединке с Бадмин Уланом был побежден, но оставлен в живых с условием, что в будущем, осуществив свои намерения и достигнув желаемого, они вновь сразятся. Когда весть о славе и величии Джангара разнеслась далеко за ее пределами, Бадмин Улан вознамерился отправить к нему двух могучих посланцев. Обеспокоенный такой вестью Джангар поведал своему окружению, что если заранее пленить и живым доставить в Бумбайскую державу Бадмин Улана, он будет в их власти, но в его стране нет исполина, кто бы смог соперничать с посланцами противника. Следуя совету мудреца Алтана Чееджи, Джангар повелевает отыскать героя, способного исполнить поручение властителя и спасти родную державу от нашествия врага. Такой добровольный спаситель является в лице юного героя Хошуна, сына Хонгора, который вместе с двумя юными богатырями отправляется исполнить героическую миссию. Юные герои пленяют и доставляют Бадмин Улана Джангару, попутно угнав табун врага.

Сюжет калмыцкой и синьцзян-ойратской версий «О пленении прекраснейшим в мире Мингъяном могучего хана Кюрмена» отмечен схождением с сюжетом тувинского сказания в ряде ключевых эпизодов - ситуации опасности, исходящей от могучего противника, нанесение героем упреждающего удара и пленении потенциального противника. В повествовании отсутствует мотив поиска героя, поскольку Джангар принимает самостоятельное решение в выборе героя, способного справиться с его поручением. Так, правитель Джангар принимает решение отправить в чужеземную страну богатыря Мингъяна. Богатырь Мингъян отправляется в страну хана-антагониста, пленяет и доставляет Кюрмин-хана в Бумбайскую державу. Плененный хан принимает подданство Джангара и благополучно отправляется домой.

Некоторыми схождениями с сюжетными эпизодами тувинского сказания отмечена глава «О подчинении Алтана Чееджи мудрого [Джангару]». Типологическое единство наблюдаются в следующих эпизодах, когда герой Джангар становится жертвой стрелы противника, спасении героя конем и его чудесного исцеления матерью юного Хонгора.

Сюжет рассказывает о том, как в пятилетнем возрасте юный Джангар попадает в плен к нойону Бёке Мёнген Шигширге, отцу богатыря Хонгора. Зная, что в скором времени его пленнику судьбой предначертано стать великим человеком - «Правителем мира», Бёке Мёнген Шигширге пытается его уничтожить и отправляет юного Джангара с поручением угнать табун мудреца-нойона Алтана Чееджи, надеясь, что герой станет жертвой его стрелы. Конь героя также спасает и доставляет хозяина домой. Смертельно раненного Джангара, по настоятельной просьбе и увещеваниям сына Хонгора, спасает и чудесным образом исцеляет жрица Зандан Герел, супруга Бёке Мёнген Шигширги.

В рассматриваемом тувинском сказании имеются мотивы сказочно-фантастического характера, повествующие о принятии героем Шил-оолом прозрачного облика и сером кролике, посланном небесным ханом, волшебным образом, умножавшим войска противника. Мотив расправы героя сламойотшельником, видимо, зародился в чуждой ламаизму среде, в среде традиционных шаманистических верований, несвойственный эпосу калмыков-ламаитов. Архаические истоки тувинского сказания просматриваются в мотиве расправы с противником, когда герой Шил-оол обезглавливает ханаантагониста и лишает жизни его супругу-хатун. В классической эпике калмыцкой и синьцзян-ойратской версий мотив расправы приближен к историческим реалиям заключенном в пленении ханаантагониста и взятием с него клятвы нести продолжительное время натуральные повинности.

\section{Заключение}

В своей исторической и эстетической динамике эпос «Джангар» прошел эволюционный путь развития от древних форм «сказочного богатырского эпоса» до циклизованного эпоса. Распространение и бытование сказаний о Джангаре в традиции тюрко-монгольских народов Центральной Азии и Сибири связано с развитым культом эпического героя Джангара и обусловлено древнейшими историко-культурными и этническими связями с ойратами, особенно сильным влияние было в период существования Джунгарского ханства.

Сказание «Богдо Чаңгар хан», созданное и сформированное в тувинской эпической традиции, в своей поэтической структуре сохранило черты своих древних самобытных культур, черты патриархального уклада и родо-племенной идеологии, матриархальных пережитков, жанрового синкретизм 
героического эпоса и волшебно-героической сказки, сказочно-мифологического пласта, восходящего к архаическим сказаниям тюрко-монгольских народов Сибири.

Тувинское сказание «Богдо Чаңгар хан» обнаруживает генетические фольклорные связи с калмыцким и ойратским «Джангаром» на уровне поэтики и стилистики, тем и сюжетов, мотивов и образов, циклической организации, где прослеживается тенденция к генеалогической циклизации поколений «отец-сын». Универсальна тематика (героического сватовства и борьбы с мифическими существами и иноземными ханами), присущая тюрко-монгольской эпике, разрабатывается в сказаниях. Помимо тематической общности, близкие соответствия обнаруживаются на уровне сюжетов и мотивов, относимых к центрально-азиатской сказочно-эпической традиции: тарха-паршица, чудесном исцелении богатыря небесной девой, поездке в страну антагониста и пленении противника и др. Сходство сюжетов наблюдается в ряде ключевых мотивов и эпизодов: в надвигающейся опасности для Джангара, исходящей от могучего противника; поиске богатыря, способного исполнить поручение властителя и спасти родную державу от нашествия врага; в явлении добровольного спасителя в лице юного героябогатыря, сына Джангара; смене обличья героем на тарха-паршивца в косульей шубе; в исполнении юным богатырем героической миссии - нанесения упреждающего удара и расправы с потенциальным противником.

\section{СПИСОК ЛИТЕРАТУРЫ}

Богдо Чаңгар хан (1973) // Ученые записки. Серия филологическая. Элиста: КНИИЯлИ. Вып. ХІ. C. $122-127$.

Джангар. Калмыцкий героический эпос (1990) / сост., подг. текстов, коммент. и словарь Н. Ц. Биткеева, Э. Б. Овалова, Ц. К. Корсункиева, А. В. Кудиярова, Н. Б. Сангаджиевой. М.: Наука. 475 с. (На калм. и русск. яз.).

Джангар. Героический эпос синьцзянских ойрат-монголов (2005) : в 3 т. Элиста: АПП «Джангар». Т. 1. 856 с. (На калм. яз.).

Джангар. Героический эпос синьцзянских ойрат-монголов (2006) : в 3 т. Элиста: АПП «Джангар». Т. 2. 831 с. (На калм. яз.).

Кичиков, А. Ш. (1973) О тувинской богатырской сказке «Богдо Чаңгар хане» // Ученые записки. Серия филологическая. Элиста: КНИИЯЛИ. Вып. ХІ. С. 118-121.

Куулар, Д. С. (2004) Тувинская версия «Джангара» // Джангар» и проблемы эпического творчества: мат-лы Межд. науч. конф. (г. Элиста, 22-24 августа 1990 г.) / отв. ред. Н. Ц. Биткеев, Э. Б. Овалов. Элиста : АПП «Джангар». 602 с. С. 143-148.

Мелетинский, Е. М. (2004) Происхождение героического эпоса. Ранние формы и архаические памятники. М. : Восточная литература. 462 с.

Орус-оол, С. М. (2011) «Джангар» и эпос тюрко-монгольских народов // Орус-оол С. М. Избранные научные труды. Абакан : ООО «Журналист». 296 с. С. 35-55.

Таубе, Э. (2004) Следы сюжетов «Джангара» в фольклоре тувинцев на Алтае // «Джангар» и проблемы эпического творчества: : мат-лы Межд. науч. конф. (г. Элиста, 22-24 августа 1990 г.) / отв. ред. Н. Ц. Биткеев, Э.Б . Овалов. Элиста : АПП «Джангар». 602 с. С. 172-189.

Дата поступления: 30.08.2019 2.

\section{REFERENCES}

Bogdo Changar Khan (1973). In: Uchenye zapiski. Elista, KNIIYaLI. Vol. XI. Pp. 122-127. (In Russ.).

Dzhangar. Kalmytskii geroicheskii epos [Jangar. The Kalmyk heroic epic] (1990). Comp., prep., comment. and glossary by N. Ts. Bitkeev et al. Moscow, Nauka. 475 p. (In Kalm. and Russ.).

Dzhangar. Geroicheskii epos sin'tszyanskikh oirat-mongolov [Jangar. The heroic epic of Xinjiang Oirat-Mongols] (2005). In 3 vols. Elista, Dzhangar. Vol. 1.856 p. (In Kalm.).

Dzhangar. Geroicheskii epos sin'tszyanskikh oirat-mongolov [Jangar. The heroic epic of Xinjiang Oirat-Mongols] (2006). In 3 vols. Elista, Dzhangar. Vol. 2. 831 p. (In Kalm.).

Kichikov, A. Sh. (1973) O tuvinskoi bogatyrskoi skazke «Bogdo Changar khane» [About the Tuvan heroic tale ‘Bogda Chagar-Khan’]. In: Uchenye zapiski. Elista, KNIIYaLI. Vol. XI. Pp. 118-121. (In Russ.). 
Kuular, D. S. (2004) Tuvinskaya versiya «Dzhangara» [A Tuvan version of the Jangar]. In: Dzhangar» $i$ problemy epicheskogo tvorchestva [The Jangar and problems of epic creativity]. Conference proceedings (Elista, 22-24 August 1990). Ed. by N. Ts. Bitkeev, E. B. Ovalov. Elista, Dzhangar. 542 p. Pp. 143-148. (In Russ.).

Meletinsky, E. M. (2004) Proiskhozhdenie geroicheskogo eposa. Rannie formy i arkhaicheskie pamyatniki [Origins of the heroic epic. Early forms and archaic monuments]. Moscow, Vostochnaya Literatura. 462 p. (In Russ.).

Orus-ool, S. M. (2011) «Dzhangar» i epos tyurko-mongol'skikh narodov [Jangar and the epic of TurkoMongols]. In: Orus-ool, S. M. Izbrannye nauchnye trudy [Selected scholarly works]. Abakan, Zhurnalist. 296 p. Pp. 35-55. (In Russ.).

Taube, E. (2004) Sledy syuzhetov «Dzhangara» v fol'klore tuvintsev na Altae [Traces of the Jangar's plots in folklore of Altaian Tuvans]. In: Dzhangar» i problemy epicheskogo tvorchestva [The Jangar and problems of epic creativity]. Conference proceedings (Elista, 22-24 August 1990). Ed. by N. Ts. Bitkeev, E. B. Ovalov. Elista, Dzhangar. 542 p. Pp. 172-189. (In Russ.).

Submission date: 30.08.2019. 